\title{
Testing the Mechanisms of Structural Models: The Case of the Mickey Mantle Effect
}

Hanming Fang, Michael Keane, Ahmed Khwaja, Martin Salm and Dan Silverman 
Testing the Mechanisms of Structural Models:

The Case of the Mickey Mantle Effect

by

\author{
Hanming Fang \\ Yale University \\ Michael Keane \\ ARC Federation Fellow, UTS \\ Research Fellow, ASU \\ Ahmed Khwaja \\ Duke University \\ Martin Salm \\ MEA, University of Mannheim \\ Dan Silverman \\ University of Michigan
}

December 2006

Acknowledgements: This work was supported by Australian Research Council grant FF0561843 to Michael Keane. 


\section{Introduction}

A well-known method of testing or validating econometric models (whether structural or otherwise) is to examine their performance in out of sample prediction. That is, given a change in the policy environment, do the key endogenous variables of the model move in ways that are in some sense "reasonably close" to the model's forecasts? Unfortunately however, as noted by Keane and Wolpin (2007), the examination of models' predictive validity is not especially common in the micro-econometrics literature.

A common feature of structural econometric models is that latent variables, not actually incorporated in the likelihood or statistical objective function used to fit the model, are key determinants of agents' behavior. For example, in Keane and Wolpin (2001), the level of parental transfers to college-aged youth is a key driver of college attendance decisions. Yet parental transfers were not actually used in the estimation of the model as they are not observed in the NLSY data the authors use. Instead they remain a latent variable that is inferred from income, changes in assets, etc. Changes in the policy regime affect college attendance in part through their effect on transfers. Keane and Wolpin (2001) can examine whether policy changes affect college attendance in the way their model predicts, but they cannot directly test the policyto-transfers-to-behavior mechanism embedded in the model as transfers are not observed.

Here, we propose that another approach to validating structural econometric models is to seek evidence that such latent behavioral mechanisms inherent in a model are in fact operative. Of course, this requires collecting data on the relevant latent variable(s). ${ }^{1}$

We present an example of this idea motivated by Khwaja (2001). He develops a structural model of health over the life cycle, incorporating sequential (bi-annual) decisions about health insurance, health investments (via preventive care and healthy or unhealthy behaviors) and medical treatment. He estimates the model using the U.S. Health and Retirement Study (HRS). Simulation of the model generates the rather surprising result that provision of subsidized (or even free) health insurance would not cause people to engage more in unhealthy or risky behaviors like drinking and smoking, or less in healthy behaviors like exercise. This runs counter to the traditional "moral hazard" story in static models of insurance, where insurance induces people to engage in more risky behaviors.

\footnotetext{
${ }^{1}$ Keane and Wolpin (2001) did examine historical data on transfers from other sources, and they argue that qualitatively it follows the patterns predicted by their model. But the additional data was inadequate to directly test the policy-to-transfers-to-schooling behavioral mechanism.
} 
The key point is that, in a dynamic model, more generous insurance can increase life expectancy, as a better insured person can afford more preventive care and better treatment should he/she become sick. Increased life expectancy, in turn, enhances one's incentive to invest in health. Technically, the reason is that, in any dynamic model, a longer planning horizon (i.e., in this case, life-span) increases returns to investment. More intuitively, if one expects to live longer, it creates an incentive to invest in health to enhance quality of life in old age. ${ }^{2}$ This dynamic effect counteracts the moral hazard effect of insurance on investment in health.

We call the mechanism whereby greater life expectancy increases investment in health the "Mickey Mantle effect," after the great Yankee slugger of the 1950s and 60s. Mantle (19311995) was legendary for having perhaps the greatest natural talent of any baseball player. But a string of serious injuries, combined with heavy drinking and serious disregard for his health, ended his career prematurely. After years of alcoholism leading ultimately to liver failure, Mantle finally died of cancer at the age of 63 . He explained his reckless behavior by noting that he never expected to live past his early 40s, as most males in his father's line had died young due to Hodgkin's disease. ${ }^{3}$ He was surprised to live into his $60 \mathrm{~s}$, and is widely attributed the quote: "If I knew I was going to live this long, I'd have taken better care of myself."

Khwaja's model predicts that if we could observe the latent variable life expectancy, then we should see the Mantle effect - a ceteris paribus positive effect of life expectancy on investment in health. If this effect were not present, it would cast serious doubt on the validity of the model, while if it is present we would gain additional confidence in the model.

The HRS does collect data on subjective life expectancy. Our goal is to look for evidence of the Mantle effect using these data, by estimating health investment decision rules including life expectancy. ${ }^{5}$ Of course, the problem we face is that life expectancy is potentially endogenous in the decision rule for investment in health, for two reasons. First, there is a reverse causality: greater investment in health should increase life expectancy, ceteris paribus. Second, there is the

\footnotetext{
${ }^{2}$ On the other hand, the expectation of greater longevity can also reduce the marginal value of additional years of life, a mechanism that would reduce investment in health. In Khwaja's model the investment increasing effects of a greater expected life span dominate.

${ }^{3}$ Mantle's father died of Hodgkin's disease at age 39, while his two uncles died at 32 and 41. Of Mantle's four sons, one died of Hodgkin's disease a year before Mantle (at age 36), while the other died of cancer in 2000. Mantle's two surviving sons are active in the Mickey Mantle Foundation, which promotes organ donations.

${ }^{4}$ This could be viewed as ex post rationalization, but Mantle made related statements in his youth. For instance, as a rookie he told the Yankee player representative: "You don't have to talk to me about pensions. I won't be around long enough to collect one."

${ }^{5}$ In principle, Khwaja might have used these data in estimation, but modeling expectations entails great difficulties.
} 
problem of omitted variables. For example, the Mantle mechanism implies that health itself influences investment, as a healthier person would, ceteris paribus, expect to live longer and therefore have a greater return to investments that increase quality of life in old age. Thus, failure to adequately control for an individual's health could create spurious correlation between life expectancy and health investment. In addition, there is also the problem that survey questions presumably measure subjective life expectancy with considerable error.

We deal with these problems by instrumenting for subjective life expectancy. Motivated by the Mantle story, we use as instruments information on the ages at death of respondents' parents (or their current ages if still alive). The idea is that these variables capture an influence on peoples' subjective life expectancy that is independent of their health status, or other factors such as income or the price of medical care or insurance. ${ }^{6}$

To clarify the nature of the problem, suppose that investments in health, life expectancy, the level of health and insurance choice are determined by the following system of equations, which can be viewed as a simple schematic representation of Khwaja's model:

(A) Investment in health $=\mathrm{f}$ (lagged health, price of investment in health, income, taste for health, life expectancy)

(B) Life expectancy $=\mathrm{g}$ (lagged health, price of health care, investment in health, environmental risk factors, genetics)

(C) Current health $=\mathrm{h}$ (lagged health, investment in health, environmental risk factors, genetics, exogenous shocks to health)

(D) Insurance coverage $=\mathrm{I}$ (lagged health, insurance plan options, income, risk aversion, taste for health, tastes for insurance plan options)

Our interest is in estimating equation (A). Assume the error term in (A) arises because (i) the "taste for health" variable and (ii) some part of lagged health are unobserved. According to equation (B), life expectancy is affected by one's rate of investment in health. Thus, life expectancy is endogenous in (A), because a person with (i) a high unobserved taste for health and/or (ii) a higher than observed level of lagged health will tend to have both a high rate of investment in health and a high life expectancy (creating spurious correlation).

\footnotetext{
${ }^{6}$ After completing this work we became aware of a recent paper by Bloom, Canning, Moore and Song (2006) that uses similar instruments to estimate effects of life expectancy on saving and the timing of retirement.
} 
A valid instrument for life expectancy in (A) is a variable that affects investment in health only through its affect on life expectancy (and not through any other channel). In the system (A)-(D), one's genetic health endowment plays this role. Thus, as suggested by the Mantle story, one way to generate an instrument is to obtain data on congenital family diseases, or proxy for the genetic endowment using parents' age at death. ${ }^{7,8}$ The key identifying assumption here is that investment is conditionally mean independent of the genetic health endowment, given the controls in (A) - i.e., life expectancy, measured health, income, prices.

Note that the variables "price of investments in health" in (A) and "price of health care" in (B) depend on prices of alcohol and tobacco, proximity to and cost of healthy food, proximity to athletic facilities, etc., as well as insurance coverage. We do not measure these variables directly, but instead proxy for them using time and region dummies (determinants of prices) and variables like education, income and risk tolerance (which drive insurance coverage). ${ }^{9}$

\section{Description of the HRS Data}

Our data come from the first six waves (1992-2002) of the HRS, which began as a panel study of the 1931 through 1941 U.S. birth cohorts (see www.hrsonline.isr.umich.edu). Participants have been interviewed every two years since 1992. Individuals in the first wave range from 51 to 61 years of age; spouses received an identical interview and could be of any age. In 1998 new cohorts born between 1942 and 1947 were added to the sample. We restrict our sample to persons age 51 to 65 at the time of the interview. For this age group we use information on all individuals and years with complete information. ${ }^{10}$ Our dependent variables

\footnotetext{
${ }^{7}$ A possible problem is that a family history of congenital disease might affect one's investment in health through other channels (e.g., due to having fewer financial resources in youth if parents were ill). However, it can be plausibly argued that this problem is resolved by conditioning on current health status in (A), as this would control for effects of family background on prior investments in health.

${ }^{8}$ According to the framework (A)-(D), measures of environmental risk factors are also potential instruments. Living in a risky environment may reduce life expectancy, but conditional on life expectancy it should not affect investment in health directly. Of course, this assumes that risky environment is not endogenous in the sense that people with low tastes for health will also choose to live in a risky environment.

${ }^{9}$ Insurance coverage may tend to be correlated with unobserved tastes for health. Thus, there may be a selection bias whereby people with greater taste for health also have more comprehensive insurance (and hence, a lower cost of investment in health). In that case, consistent estimation of (A) would require us to deal with this selection problem. That in turn, would require estimating (A) jointly with the choice model for insurance coverage in (D).

${ }^{10}$ In the HRS wave 1-6, there were 56,567 observations in the 51-65 age range. Of these, 7,564 were dropped because of missing information on longevity expectations, 3,087 because of missing information on age and death of parents, 1,557 because they had not answered the question about risk aversion. In addition 26 observations had missing information on education, 48 on birth region, and 38 had non-responses to questions on worsening of health conditions, giving an analysis sample of 44,238. There are 275 missing observations for the smoking question.
} 
include binary indicators for whether a respondent currently smokes, drinks heavily (average consumption of 3 or more drinks per day), or is obese (Body Mass Index $>30$ ). Our analysis sample contains 44,238 observations (which is reduced to 43,963 in the case of the smoking regression, as this variable is missing for 275 respondents).

Our measure of subjective life expectancy is the answer to a question about the percent chance a respondent will live to age 75 or more. Prior studies have shown that such longevity probabilities are generally good predictors of actual longevity (see Hurd and McGarry (1995, 2002), Smith, Taylor and Sloan (2001) and Khwaja, Sloan and Chung (2005)). Control variables include the respondents' age, gender, race (black vs. not black), ethnicity (Hispanic vs. not Hispanic), and marital status, household income, net household wealth, education, and indicators for whether the respondents' father and mother had high school degrees. We also include a measure of respondents' degree of relative risk aversion, based on a question about the willingness to accept a lifetime income gamble (see Barsky et al. (1997)). ${ }^{11}$

We control for health using a detailed list of health indicators. These include indicators of self-assessed health (i.e., excellent, very good or better, good or better, or fair or better), as well as a large number of objective measures, such as: whether the respondent had a recent overnight stay in a hospital, the number of limitations in activities of daily living (ADLs), ${ }^{12}$ and binary indicators for whether the respondent was ever diagnosed with hypertension, diabetes, cancer, lung disease, heart problems, stroke, mental disease, or arthritis/rheumatism. We also include a number of variables measuring changes in health status since the last interview, such as the change in self-reported health status, whether there was a first diagnosis of any of the conditions listed above, and, if the respondent already had one of these physician-diagnosed medical conditions, whether the condition got worse. Finally, we include binary variables set to one if any of the health measures is missing.

Our instruments include the age at death of respondents' parents (or their current age if still alive), as well as age ${ }^{2}$ age $^{3}$ and binary indicators of whether the father or mother died at an age that fell in the range of $<65,66$ to 70,71 to 75,76 to 80,81 to 85 , or $86+$.

Table 1 contains a complete list of variables used in the analysis, along with means and standard deviations. $58 \%$ of respondents are female. The average age is 58 and $65 \%$ expect to

\footnotetext{
${ }^{11}$ This question was not asked of all respondents in all waves. If a current response was not available, we used the last available answer.

${ }^{12}$ ADLs are whether the individual is able to independently walk, dress, bathe, eat, get into bed, and use the toilet.
} 
live to age $75+.78 \%$ report being in good or better health, while $49 \%$ report very good or better. The average age at death of respondents' mothers is 74.4 while that of fathers was $70.7 .^{13}$

\section{Empirical Results}

Given the large number of health measures, it is difficult to interpret their coefficients in regressions for life expectancy or for health investment. Thus, we conducted the factor analysis described in Table 2. We decided to keep the first 4 factors, which together explain the bulk of the covariance amongst the health indicators. The first factor, which is by far the most important, is a poor health factor with substantial negative loadings on self-reported health and substantial positive loadings on all the physician diagnosed conditions. Factors 2 through 4 are all positive health factors whose interpretation is much subtler. ${ }^{14}$

Table 3 reports the $1^{\text {st }}$ stage results from our two-stage least squares (2SLS) procedure. The dependent variable is our measure of life expectancy - the expected probability of living to age $75+$. The first column reports results using the 4 health factors, while the second column includes all the separate health indicators from Table 1. We reports results only for the subsample used in the smoking analysis $(\mathrm{N}=43,963)$ as the results for the full sample used in the heavy drinking and high-BMI analysis are almost identical.

Clearly, health Factor 1 is a far more important determinant of life expectancy than the other factors. A one standard deviation increase in (poor) health Factor 1 reduces expected probability of living to age $75+$ by $(-11.058)(.862)=9.5$ percentage points. Women's subjective probability of living to $75+$ is about 3.5 points greater than men, ceteris paribus, while that for Blacks is almost 7 points greater than for whites. An additional 4 years of education raises this probability more than 2 points. Interestingly, marriage and assets are not significant and income, while significant, has a very small effect. The point estimates imply that roughly a 300 thousand dollar increase in annual income is needed to raise the subjective probability by just 1 point.

The parental age at death variables have large and significant effects in the expected direction. For instance, having a father whose age at death was 65 or less reduces the subjective probability of living to $75+$ by 6.6 percentage points, ceteris paribus. The F-test for the joint significance of the parental age at death variables is 23.19 in column (1) and 24.06 in column (2).

\footnotetext{
${ }^{13}$ These figures include current age for parents who are still alive (36\% of mothers and $13 \%$ of fathers).

${ }^{14}$ Factors 2 and 3 load positively on self-reported health but also load positively on stroke indicators. But while 2 loads negatively on the change in self-reported health, 3 loads positively. Factor 4 loads positively on self-reported health and negatively on hypertension and diabetes indicators. But it also loads positively on ADL limitations.
} 
Table 4 reports OLS regressions of our three health investment measures (smoking, heavy drinking and high-BMI) on our life expectancy measure (the subjective probability of living to age $75+$ ) along with an extensive set of controls for socio-demographics and health. The OLS results seem to provide some modest support for the Mantle effect. For instance, in the smoking regressions in columns (1)-(2), the subjective probability of living to age $75+$ has $t$ statistics in the 9 to 10 range. The point estimates imply that a 10-percentage point increase in this subjective probability reduces the probability of smoking by about 1 percentage point.

Point estimates for heavy drinking are highly significant, but an order of magnitude smaller. However, the percent of respondents who report heavy drinking is also an order of magnitude smaller than that who report smoking (see Table 1), so in percentage terms the effect on behavior is similar. For high-BMI our results are not significant, statistically or quantitatively.

Table 5 reports our main IV results using parents' age at death as the instruments for life expectancy. Here, the results are mixed. Those for smoking in columns (1)-(2) seem to provide strong support for the Mantle effect. Subjective life expectancy is highly significant, and the point estimates imply that OLS greatly understates the strength of the effect. Specifically, they imply that, ceteris paribus, a 10-percentage point increase in subjective probability of living to age $75+$ reduces the probability of smoking by about 2.3 to 2.7 percentage points. As the percent of respondents who smoke is $22.6 \%$ (see Table 1) these represent decreases of 10 to $12 \%$.

In contrast, for heavy drinking we obtain point estimates that are insignificant and of the wrong sign. The evidence for high-BMI is mixed. The point estimates are quantitatively fairly large (at least half as great as for smoking) and of the right sign, but just barely significant at the $5 \%$ level in column (5) and not significant in column (6).

\section{Conclusion}

We have argued that testing the latent mechanisms of structural models, independent of full-blown structural estimation, can be a valuable model validation tool. This perspective has the benefit that it can potentially rationalize much of the descriptive or IV-based empirical work being done in economics as contributing to the structural research program. As a specific example of this idea, we attempt to find evidence for the "Mantle effect" that plays a key role in Khwaja's (2001) structural model of investment in health. We find clear evidence for the effect with respect to smoking, but mixed evidence with respect to heavy drinking and high-BMI. 


\section{REFERENCES}

Barsky, Robert B., Juster, F.T. and Kimball, Miles. "Preference Parameters and Behavioral Heterogeneity: An Experimental Approach in the Health and Retirement Study." Quarterly Journal of Economics, 112 (2), 1997, pp. 537-579.

Bloom, David E.; Canning, David; Moore, Michael and Song, Younghwan. "The Effect of Subjective Survival Probabilities on Retirement and Wealth in the United States." National Bureau of Economic Research Working Paper No. 12688, November 2006.

Hurd, Michael D. and McGarry, Kathleen. "Evaluation of the Subjective Probabilities of Survival.” Journal of Human Resources, 30 (Supplement), 1995, S268-92.

Hurd, Michael D. and McGarry, Kathleen. "The Predictive Validity of Subjective Probabilities of Survival.’ Economic Journal, 112 (October), 2002, pp. 966-85.

Keane, Michael P. and Wolpin, Kenneth I. “Exploring the Usefulness of a Non-Random Holdout Sample for Model Validation: Welfare Effects on Female Behavior.” International Economic Review, forthcoming, 2007.

Keane, Michael P. and Wolpin, Kenneth I. “The Effect of Parental Transfers and Borrowing Constraints on Educational Attainment." International Economic Review, 42(4), 2001, pp. 10511103.

Khwaja, Ahmed; Sloan, Frank A. and Chung, Sukyung. "The Relationship Between Individual Expectations and Behaviors: Evidence on Mortality Expectations and Smoking Decisions." Mimeo, Duke University, 2005.

Khwaja, Ahmed. "Health Insurance, Habits and Health Outcomes: A Dynamic Stochastic Model of Investment in Health" Unpublished Ph.D. dissertation, University of Minnesota, 2001.

Smith, V. Kerry; Taylor, Donald H., Jr. and Sloan, Frank A. ““'Longevity Expectations and Death: Can People Predict Their Own Demise?” American Economic Review, 91(4), 2001, pp. 1126-1134. 
Table 1: Summary Statistics

\begin{tabular}{|c|c|c|}
\hline Variable & Mean & Std. Dev. \\
\hline \multicolumn{3}{|l|}{ Dependent Variables } \\
\hline Smoking & 0.226 & 0.418 \\
\hline Heavy Drinking & 0.034 & 0.183 \\
\hline High BMI & 0.269 & 0.443 \\
\hline \multicolumn{3}{|l|}{ Explanatory Variables } \\
\hline Subjective probability of living to age $75+$ & 65.182 & 29.063 \\
\hline Female & 0.579 & 0.493 \\
\hline Black & 0.146 & 0.354 \\
\hline Hispanic & 0.075 & 0.264 \\
\hline Age & 58.159 & 3.927 \\
\hline Years of education & 12.466 & 2.981 \\
\hline Married & 0.731 & 0.443 \\
\hline Household income (in 1,000 USD) & 58.034 & 95.760 \\
\hline Household wealth (in 1,000 USD) & 295.961 & 882.010 \\
\hline Risk tolerance & 0.242 & 0.143 \\
\hline Father has high school degree & 0.441 & 0.496 \\
\hline Mother has high school degree & 0.458 & 0.498 \\
\hline \multicolumn{3}{|l|}{ Health Indicators } \\
\hline Self reported health excellent & 0.182 & 0.386 \\
\hline Self reported health very good or better & 0.492 & 0.499 \\
\hline Self reported health good or better & 0.782 & 0.412 \\
\hline Self reported health fair or better & 0.932 & 0.250 \\
\hline Change in self reported health ( $1=$ better, $5=$ worse $)$ & 2.950 & 0.852 \\
\hline Number of ADL limitations & 0.151 & 0.581 \\
\hline Change in number of ADL limitations & 0.027 & 0.473 \\
\hline Hospital stay in last two years & 0.171 & 0.376 \\
\hline Hypertension diagnosis ever & 0.396 & 0.489 \\
\hline Diabetes diagnosis ever & 0.115 & 0.320 \\
\hline Cancer diagnosis ever & 0.070 & 0.255 \\
\hline Lung disease diagnosis ever & 0.069 & 0.255 \\
\hline Heart problems diagnosis ever & 0.136 & 0.342 \\
\hline Stroke diagnosis ever & 0.032 & 0.176 \\
\hline Mental diseases diagnosis ever & 0.112 & 0.316 \\
\hline Arthritis diagnosis ever & 0.445 & 0.497 \\
\hline Hypertension first diagnosis last 2 years & 0.032 & 0.176 \\
\hline Diabetes first diagnosis last 2 years & 0.016 & 0.125 \\
\hline Cancer first diagnosis last 2 years & 0.012 & 0.109 \\
\hline Lung disease first diagnosis last 2 years & 0.010 & 0.099 \\
\hline Heart problem first diagnosis last 2 years & 0.019 & 0.136 \\
\hline Stroke first diagnosis last 2 years & 0.006 & 0.077 \\
\hline Mental disease first diagnosis last 2 years & 0.015 & 0.122 \\
\hline Arthritis first diagnosis last 2 years & 0.044 & 0.206 \\
\hline Hypertension worse & 0.009 & 0.098 \\
\hline Diabetes worse & 0.007 & 0.085 \\
\hline Cancer worse & 0.001 & 0.037 \\
\hline Lung disease worse & 0.007 & 0.088 \\
\hline Heart problems worse & 0.007 & 0.085 \\
\hline Mental disease worse & 0.005 & 0.076 \\
\hline
\end{tabular}


Stroke remaining problems worse

$\begin{array}{ll}0.009 & 0.097 \\ 0.003 & 0.057 \\ 0.037 & 0.189\end{array}$

Health status variable missing
Change in health variable missing

0.057

Health Factors $\S^{\S}$

Health factor 1

Health factor 2

$-0.050$

0.861

Health factor 3

$-0.041$

0.732

Health factor 4

0.037

0.720

$-0.005$

0.699

Instrumental Variables

Age of mother ${ }^{+}$

Age of father ${ }^{+}$

Mother age at death $\leq 65$

0.200

0.400

Mother age at death 66 to 70

0.070

0.256

Mother age at death 71 to 75

0.096

0.295

Mother age at death 76 to 80

0.100

0.300

Mother age at death 81 to 85

0.098

0.297

Mother age at death $>85$

0.079

0.271

Father age at death $\leq 65$

0.312

0.463

Father age at death 66 to 70

0.112

0.315

Father age at death 71 to 75

0.137

0.344

Father age at death 76 to 80

0.121

0.327

Father age at death 81 to 85

0.101

0.301

Father age at death $>85$

0.082

0.274

Number of observations ${ }^{++}$

43,963

$\S$ The four health factors are constructed from the health indicators via factor analysis (see Table 2).

${ }^{+}$Age is either current age or age at death. $36 \%$ of mothers and $13 \%$ of fathers are still alive.

${ }^{++}$Sample statistics refer to the sample used in the smoking regression. 
Table 2: Factor Loadings for the Health Variables

\begin{tabular}{|c|c|c|c|c|}
\hline Variable & $\begin{array}{l}\text { Health } \\
\text { factor } 1\end{array}$ & $\begin{array}{l}\text { Health } \\
\text { factor } 2\end{array}$ & $\begin{array}{l}\text { Health } \\
\text { factor } 3\end{array}$ & $\begin{array}{l}\text { Health } \\
\text { factor } 4\end{array}$ \\
\hline Self reported health excellent & -0.371 & 0.085 & 0.169 & 0.237 \\
\hline Self reported health very good or better & -0.576 & 0.089 & 0.221 & 0.224 \\
\hline Self reported health good or better & -0.680 & 0.044 & 0.170 & 0.012 \\
\hline Self reported health fair or better & -0.576 & -0.010 & 0.084 & -0.176 \\
\hline Change in self reported health ( 1 to 5) & 0.384 & -0.510 & 0.425 & 0.019 \\
\hline Number of ADL limitations ( 0 to 6 ) & 0.557 & 0.112 & 0.050 & 0.406 \\
\hline Change in number of ADL limitations & 0.256 & 0.064 & 0.098 & 0.392 \\
\hline Hospital stay in last two years & 0.411 & 0.049 & -0.055 & -0.050 \\
\hline Hypertension diagnosis ever & 0.325 & -0.008 & -0.057 & -0.224 \\
\hline Diabetes diagnosis ever & 0.348 & -0.003 & -0.065 & -0.261 \\
\hline Cancer diagnosis ever & 0.138 & -0.050 & -0.115 & 0.028 \\
\hline Lung disease diagnosis ever & 0.341 & -0.079 & -0.119 & 0.187 \\
\hline Heart problems diagnosis ever & 0.404 & 0.009 & -0.096 & -0.134 \\
\hline Stroke diagnosis ever & 0.369 & 0.462 & 0.380 & -0.143 \\
\hline Mental diseases diagnosis ever & 0.373 & -0.026 & -0.103 & 0.107 \\
\hline Arthritis diagnosis ever & 0.327 & -0.106 & -0.080 & -0.042 \\
\hline Hypertension first diagnosis last 2 years & 0.087 & -0.043 & 0.015 & -0.095 \\
\hline Diabetes first diagnosis last 2 years & 0.139 & -0.042 & -0.022 & -0.184 \\
\hline Cancer first diagnosis last 2 years & 0.116 & -0.063 & -0.073 & 0.012 \\
\hline Lung disease first diagnosis last 2 years & 0.169 & -0.061 & -0.051 & 0.112 \\
\hline Heart problem first diagnosis last 2 years & 0.197 & -0.032 & -0.037 & -0.113 \\
\hline Stroke first diagnosis last 2 years & 0.244 & 0.326 & 0.330 & -0.084 \\
\hline Mental disease first diagnosis last 2 years & 0.182 & -0.027 & -0.020 & 0.067 \\
\hline Arthritis first diagnosis last 2 years & 0.074 & -0.071 & 0.017 & -0.035 \\
\hline Hypertension worse & 0.193 & -0.022 & 0.036 & 0.021 \\
\hline Diabetes worse & 0.195 & -0.034 & 0.009 & -0.023 \\
\hline Cancer worse & 0.063 & -0.025 & -0.022 & 0.021 \\
\hline Lung disease worse & 0.217 & -0.052 & -0.016 & 0.161 \\
\hline Heart problems worse & 0.239 & 0.018 & 0.045 & 0.028 \\
\hline Mental disease worse & 0.192 & -0.015 & 0.010 & 0.113 \\
\hline Stroke remaining problems worse & 0.315 & 0.431 & 0.379 & -0.082 \\
\hline Health status variable missing & 0.043 & 0.146 & -0.162 & 0.038 \\
\hline Change in health variable missing & -0.078 & 0.556 & -0.526 & 0.066 \\
\hline Eigenvalue & 3.405 & 1.179 & 1.088 & 0.802 \\
\hline
\end{tabular}

Note: For ease of interpretation, the more important negative loadings on good health indicators (or positive loadings on poor health measures) are highlighted in red. Similarly, the more important positive loadings on good health indicators (or negative loadings on bad health indicators) are highlighted in blue. 
Table 3: $1^{\text {st }}$ Stage IV Regression Results: Predicting Life Expectancy ${ }^{\S}$

\begin{tabular}{|c|c|c|}
\hline \multicolumn{3}{|c|}{ Dependent Variable: Subjective probability of living to age $75+$} \\
\hline & (1) & $(2)^{+}$ \\
\hline Independent Variable & Health factors & Health variables \\
\hline \multirow[t]{2}{*}{ Female } & $3.747 * * *$ & $3.497 * * *$ \\
\hline & $(0.395)$ & $(0.395)$ \\
\hline \multirow[t]{2}{*}{ Black } & $6.678 * * *$ & $6.865 * * *$ \\
\hline & $(0.647)$ & $(0.644)$ \\
\hline \multirow[t]{2}{*}{ Hispanic } & $-3.904 * * *$ & $-3.523 * * *$ \\
\hline & $(0.934)$ & $(0.932)$ \\
\hline \multirow[t]{2}{*}{ Age } & $0.392 * * *$ & $0.365 * * *$ \\
\hline & $(0.050)$ & $(0.051)$ \\
\hline \multirow[t]{2}{*}{ Years of education } & $0.652 * * *$ & $0.558 * * *$ \\
\hline & $(0.075)$ & $(0.075)$ \\
\hline \multirow[t]{2}{*}{ Married } & 0.688 & 0.643 \\
\hline & $(0.443)$ & $(0.437)$ \\
\hline \multirow[t]{2}{*}{ Health factor 1} & $-11.058 * * *$ & \\
\hline & $(0.242)$ & \\
\hline \multirow[t]{2}{*}{ Health factor 2} & $0.693 * * *$ & \\
\hline & $(0.228)$ & \\
\hline \multirow[t]{2}{*}{ Health factor 3} & $2.720 * * *$ & \\
\hline & $(0.233)$ & \\
\hline \multirow[t]{2}{*}{ Health factor 4} & $0.662 * * *$ & \\
\hline & $(0.258)$ & \\
\hline \multirow[t]{2}{*}{ Household income (in 1,000 USD) } & $0.003 * * *$ & $0.003 * *$ \\
\hline & $(0.001)$ & $(0.001)$ \\
\hline \multirow[t]{2}{*}{ Household wealth (in 1,000 USD) } & 0.0001 & 0.0001 \\
\hline & $(0.0001)$ & $(0.0001)$ \\
\hline \multirow[t]{2}{*}{ Risk tolerance } & -0.394 & -0.462 \\
\hline & $(1.311)$ & $(1.296)$ \\
\hline \multirow[t]{2}{*}{ Father has high school degree } & 0.625 & 0.622 \\
\hline & $(0.448)$ & $(0.442)$ \\
\hline \multirow[t]{2}{*}{ Mother has high school degree } & $1.033 * *$ & $0.992 * *$ \\
\hline & $(0.454)$ & $(0.449)$ \\
\hline \multirow[t]{2}{*}{ Mother age at death $\leq 65^{++}$} & $-7.288 * * *$ & $-7.487 * * *$ \\
\hline & $(1.404)$ & $(1.393)$ \\
\hline \multirow[t]{2}{*}{ Mother age at death 66 to 70} & $-4.856 * * *$ & $-4.986 * * *$ \\
\hline & $(1.049)$ & $(1.037)$ \\
\hline \multirow[t]{2}{*}{ Mother age at death 71 to 75} & $-3.505 * * *$ & $-3.556^{* * *}$ \\
\hline & $(0.803)$ & $(0.794)$ \\
\hline \multirow[t]{2}{*}{ Mother age at death 76 to 80} & $-3.112 * * *$ & $-3.116 * * *$ \\
\hline & $(0.706)$ & $(0.699)$ \\
\hline \multirow[t]{2}{*}{ Mother age at death 81 to 85} & 0.103 & 0.138 \\
\hline & $(0.631)$ & $(0.622)$ \\
\hline Mother age at death $>85$ & -0.824 & -0.840 \\
\hline & $(0.746)$ & $(0.734)$ \\
\hline Father age at death $\leq 65^{++}$ & $-6.623 * * *$ & $-6.628 * * *$ \\
\hline & $(1.532)$ & $(1.509)$ \\
\hline Father age at death 66 to 70 & $-3.933 * * *$ & $-3.919 * * *$ \\
\hline & $(1.124)$ & $(1.111)$ \\
\hline Father age at death 71 to 75 & $-3.391 * * *$ & $-3.363 * * *$ \\
\hline & $(0.902)$ & $(0.892)$ \\
\hline Father age at death 76 to 80 & $-1.349 * *$ & $-1.310^{*}$ \\
\hline & $(0.771)$ & $(0.763)$ \\
\hline
\end{tabular}




\begin{tabular}{|c|c|c|}
\hline Father age at death 81 to 85 & $\begin{array}{l}0.025 \\
(0.695)\end{array}$ & $\begin{array}{l}0.013 \\
(0.686)\end{array}$ \\
\hline Father age at death $>85$ & $\begin{array}{l}0.905 \\
(0.792)\end{array}$ & $\begin{array}{l}0.835 \\
(0.786)\end{array}$ \\
\hline Age of mother ${ }^{++}$ & $\begin{array}{l}-0.609 \\
(0.542)\end{array}$ & $\begin{array}{l}-0.497 \\
(0.541)\end{array}$ \\
\hline Age of mother ${ }^{\wedge} 2$ & $\begin{array}{l}0.005 \\
(0.009)\end{array}$ & $\begin{array}{l}0.003 \\
(0.009)\end{array}$ \\
\hline Age of mother ${ }^{\wedge} 3$ & $\begin{array}{l}0.00001 \\
(0.00004)\end{array}$ & $\begin{array}{l}>-0.00001 \\
(0.00004)\end{array}$ \\
\hline Age of father ${ }^{+++}$ & $\begin{array}{l}-0.339 \\
(0.622)\end{array}$ & $\begin{array}{l}-0.311 \\
(0.614)\end{array}$ \\
\hline Age of father ${ }^{\wedge} 2$ & $\begin{array}{l}0.001 \\
(0.010)\end{array}$ & $\begin{array}{l}0.0007 \\
(0.010)\end{array}$ \\
\hline Age of father $\wedge 3$ & $\begin{array}{l}0.00001 \\
(0.00005)\end{array}$ & $\begin{array}{l}0.00001 \\
(0.00005)\end{array}$ \\
\hline F-test for age polynomials & 10.07 & 9.90 \\
\hline R-squared & 0.177 & 0.187 \\
\hline Partial R-squared (identifying instruments) & 0.021 & 0.022 \\
\hline F-test for excluded instruments & 23.19 & 24.06 \\
\hline Observations & 43,963 & 43,963 \\
\hline \multicolumn{3}{|c|}{$*$ significant at $10 \% ; * *$ significant at $5 \% ; * * *$ significant at $1 \%$} \\
\hline \multicolumn{3}{|c|}{ Huber-White standard errors in brackets, clustered at respondent level } \\
\hline \multirow{2}{*}{\multicolumn{3}{|c|}{$\begin{array}{l}\text { Coefficients for wave fixed effects and birth region are included but not shown. } \\
\S \text { The table reports the } 1^{\text {st }} \text { stage results for the sample used in the smoking }\end{array}$}} \\
\hline & & \\
\hline \multicolumn{3}{|c|}{$\begin{array}{l}\text { regression. The } 1^{\text {st }} \text { stage results for heavy drinking and high BMI are very similar, } \\
\text { as the sample size is only reduced to } 44,238 \text {. }\end{array}$} \\
\hline \multicolumn{3}{|c|}{$\begin{array}{l}\text { All the health indicators in Table } 1 \text { are included in the regression in column } 2 \text {, but } \\
\text { the coefficients are not shown. }\end{array}$} \\
\hline \multicolumn{3}{|c|}{$\begin{array}{l}\text { The omitted categories for the father and mother age at death dummies are } \\
\text { mother still alive and father still alive. }\end{array}$} \\
\hline
\end{tabular}


Table 4: Ordinary Least Squares Regression Results

\begin{tabular}{|c|c|c|c|c|c|c|}
\hline & \multicolumn{2}{|c|}{ Smoking } & \multicolumn{2}{|c|}{ Heavy drinking } & \multicolumn{2}{|c|}{ High BMI } \\
\hline & $\begin{array}{c}\text { (1) } \\
\text { Health } \\
\text { factors }\end{array}$ & $\begin{array}{c}(2)^{+} \\
\text {Health } \\
\text { variables }\end{array}$ & $\begin{array}{c}(3) \\
\text { Health } \\
\text { factors }\end{array}$ & $\begin{array}{c}(4)^{+} \\
\text {Health } \\
\text { variables }\end{array}$ & $\begin{array}{c}(5) \\
\text { Health } \\
\text { factors }\end{array}$ & $\begin{array}{c}(6)^{+} \\
\text {Health } \\
\text { variables }\end{array}$ \\
\hline Subj. Prob. of living & $-0.0010 * * *$ & $-0.0009 * * *$ & $-0.0001 * * *$ & $-0.0001 * * *$ & -0.0001 & 0.00006 \\
\hline to age $75+$ & $(0.0001)$ & $(0.0001)$ & $(0.00004)$ & $(0.00004)$ & $(0.0001)$ & $(0.0001)$ \\
\hline Female & $\begin{array}{l}-0.046^{* * *} \\
(0.007)\end{array}$ & $\begin{array}{l}-0.049 * * * \\
(0.007)\end{array}$ & $\begin{array}{l}-0.055^{* * * *} \\
(0.003)\end{array}$ & $\begin{array}{l}-0.057 * * * \\
(0.003)\end{array}$ & $\begin{array}{l}0.017 * * \\
(0.007)\end{array}$ & $\begin{array}{l}0.012 \\
(0.007)\end{array}$ \\
\hline Black & $\begin{array}{l}-0.030^{* * *} \\
(0.011)\end{array}$ & $\begin{array}{l}-0.013 \\
(0.011)\end{array}$ & $\begin{array}{l}-0.005^{*} \\
(0.003)\end{array}$ & $\begin{array}{l}-0.005^{*} \\
(0.003)\end{array}$ & $\begin{array}{l}0.107 * * * \\
(0.012)\end{array}$ & $\begin{array}{l}0.076^{* *} \\
(0.012)\end{array}$ \\
\hline Hispanic & $\begin{array}{l}-0.98 * * * \\
(0.016)\end{array}$ & $\begin{array}{l}-0.091 * * * \\
(0.015)\end{array}$ & $\begin{array}{l}-0.012 * * \\
(0.005)\end{array}$ & $\begin{array}{l}-0.012 * * \\
(0.005)\end{array}$ & $\begin{array}{l}0.043 * * * \\
(0.016)\end{array}$ & $\begin{array}{l}0.035^{* *} \\
(0.016)\end{array}$ \\
\hline Age & $\begin{array}{l}-0.008^{* * *} \\
(0.0008)\end{array}$ & $\begin{array}{l}-0.008 * * * \\
(0.0008)\end{array}$ & $\begin{array}{l}-0.0004 \\
(0.0003)\end{array}$ & $\begin{array}{l}-0.0005 \\
(0.0003)\end{array}$ & $\begin{array}{l}-0.007 * * * \\
(0.0008)\end{array}$ & $\begin{array}{l}-0.008 * * * \\
(0.0008)\end{array}$ \\
\hline Years of education & $\begin{array}{l}-0.016^{* * *} \\
(0.001)\end{array}$ & $\begin{array}{l}-0.014 * * * \\
(0.001)\end{array}$ & $\begin{array}{l}-0.001 * * * \\
(0.0005)\end{array}$ & $\begin{array}{l}-0.001 * * * \\
(0.0005)\end{array}$ & $\begin{array}{l}-0.002 \\
(0.001)\end{array}$ & $\begin{array}{l}-0.002 * \\
(0.001)\end{array}$ \\
\hline Married & $\begin{array}{l}-0.110^{* * * *} \\
(0.008)\end{array}$ & $\begin{array}{l}-0.107 * * * \\
(0.008)\end{array}$ & $\begin{array}{l}-0.017 * * * \\
(0.003)\end{array}$ & $\begin{array}{l}-0.016 * * * \\
(0.003)\end{array}$ & $\begin{array}{l}0.013 \\
(0.008)\end{array}$ & $\begin{array}{l}0.011 \\
(0.008)\end{array}$ \\
\hline Health factor 1 & $\begin{array}{l}0.015 * * * \\
(0.004)\end{array}$ & & $\begin{array}{l}-0.002 * * \\
(0.001)\end{array}$ & & $\begin{array}{l}0.082 * * * \\
(0.004)\end{array}$ & \\
\hline Health factor 2 & $\begin{array}{l}-0.011 * * * \\
(0.003)\end{array}$ & & $\begin{array}{l}-0.002 * * \\
(0.001)\end{array}$ & & $\begin{array}{l}-0.012 * * * \\
(0.003)\end{array}$ & \\
\hline Health factor 3 & $\begin{array}{l}-0.009^{* *} \\
(0.003)\end{array}$ & & $\begin{array}{l}0.001 \\
(0.001)\end{array}$ & & $\begin{array}{l}-0.040^{* * * *} \\
(0.004)\end{array}$ & \\
\hline Health factor 4 & $\begin{array}{l}0.025 * * * \\
(0.004)\end{array}$ & & $\begin{array}{l}0.003 * * * \\
(0.001)\end{array}$ & & $\begin{array}{l}0.061 * * \\
(0.004)\end{array}$ & \\
\hline $\begin{array}{l}\text { Household income } \\
\text { (in } 1,000 \text { USD) }\end{array}$ & $\begin{array}{l}-0.00009 * * * \\
(0.00002)\end{array}$ & $\begin{array}{l}-0.00008 * * * \\
(0.00002)\end{array}$ & $\begin{array}{l}<0.00001 \\
(0.00001)\end{array}$ & $\begin{array}{l}<0.00001 \\
(0.00001)\end{array}$ & $\begin{array}{l}-0.00004 \\
(0.00003)\end{array}$ & $\begin{array}{l}-0.00003 \\
(0.00003)\end{array}$ \\
\hline $\begin{array}{l}\text { Household wealth } \\
\text { (in } 1,000 \text { USD) }\end{array}$ & $\begin{array}{l}-0.00001 * * * \\
(<0.00001)\end{array}$ & $\begin{array}{l}-0.00001 * * * \\
(<0.00001)\end{array}$ & $\begin{array}{l}<0.00001 \\
(<0.00001)\end{array}$ & $\begin{array}{l}<0.00001 \\
(<0.00001)\end{array}$ & $\begin{array}{l}<0.00001 \\
(<0.00001)\end{array}$ & $\begin{array}{l}<0.00001 \\
(<0.00001)\end{array}$ \\
\hline Risk tolerance & $\begin{array}{l}0.068 * * * \\
(0.024)\end{array}$ & $\begin{array}{l}0.066^{* * * *} \\
(0.023)\end{array}$ & $\begin{array}{l}0.019 * * \\
(0.009)\end{array}$ & $\begin{array}{l}0.020 * * \\
(0.0009)\end{array}$ & $\begin{array}{l}-0.042 * \\
(0.024)\end{array}$ & $\begin{array}{l}-0.033 \\
(0.023)\end{array}$ \\
\hline $\begin{array}{l}\text { Father has high } \\
\text { school degree }\end{array}$ & $\begin{array}{l}0.003 \\
(0.008)\end{array}$ & $\begin{array}{l}0.006 \\
(0.008)\end{array}$ & $\begin{array}{l}0.0009 \\
(0.003)\end{array}$ & $\begin{array}{l}0.001 \\
(0.003)\end{array}$ & $\begin{array}{l}-0.018 * * \\
(0.008)\end{array}$ & $\begin{array}{l}-0.019 * * \\
(0.008)\end{array}$ \\
\hline $\begin{array}{l}\text { Mother has high } \\
\text { school degree }\end{array}$ & $\begin{array}{l}0.0002 \\
(0.008)\end{array}$ & $\begin{array}{l}-0.0002 \\
(0.008)\end{array}$ & $\begin{array}{l}0.003 \\
(0.003)\end{array}$ & $\begin{array}{l}0.003 \\
(0.003)\end{array}$ & $\begin{array}{l}-0.0006 \\
(0.008)\end{array}$ & $\begin{array}{l}0.001 \\
(0.008)\end{array}$ \\
\hline $\mathrm{R}$ - squared & 0.05 & 0.07 & 0.03 & 0.03 & 0.06 & 0.09 \\
\hline Observations & 43,963 & 43,963 & 44,238 & 44,238 & 44,238 & 44,238 \\
\hline
\end{tabular}

* significant at $10 \% ; * *$ significant at $5 \% ; * * *$ significant at $1 \%$

Huber-White standard errors in brackets, clustered at respondent level.

Wave fixed effects and birth region dummies are included but their coefficients are not shown.

${ }^{+}$All the health indicators listed in Table 1 are included, but their coefficients are not shown. 
Table 5: IV Regression Results: $2^{\text {nd }}$ Stage

\begin{tabular}{|c|c|c|c|c|c|c|}
\hline & \multicolumn{2}{|c|}{ Smoking } & \multicolumn{2}{|c|}{ Heavy drinking } & \multicolumn{2}{|c|}{ High BMI } \\
\hline & $\begin{array}{c}\text { (1) } \\
\text { Health } \\
\text { factors }\end{array}$ & $\begin{array}{c}(2)^{+} \\
\text {Health } \\
\text { variables }\end{array}$ & $\begin{array}{c}(3) \\
\text { Health } \\
\text { factors }\end{array}$ & $\begin{array}{c}(4)^{+} \\
\text {Health } \\
\text { variables }\end{array}$ & $\begin{array}{c}\text { (5) } \\
\text { Health } \\
\text { factors }\end{array}$ & $\begin{array}{c}(6)^{+} \\
\text {Health } \\
\text { variables }\end{array}$ \\
\hline Subj. Prob. of living & $-0.0023 * *$ & $-0.0027 * * *$ & 0.0004 & 0.0003 & $-0.0018 * *$ & -0.0012 \\
\hline to age $75+$ & $(0.0009)$ & $(0.0008)$ & $(0.0003)$ & $(0.0003)$ & $(0.0009)$ & $(0.0009)$ \\
\hline Female & $\begin{array}{l}-0.041^{* * * *} \\
(0.008)\end{array}$ & $\begin{array}{l}-0.043 * * * \\
(0.008)\end{array}$ & $\begin{array}{l}-0.058 * * * \\
(0.003)\end{array}$ & $\begin{array}{l}-0.059 * * * \\
(0.003)\end{array}$ & $\begin{array}{l}0.025 * * * \\
(0.008)\end{array}$ & $\begin{array}{l}0.016^{* *} \\
(0.008)\end{array}$ \\
\hline Black & $\begin{array}{l}-0.022^{*} \\
(0.013)\end{array}$ & $\begin{array}{l}-0.001 \\
(0.013)\end{array}$ & $\begin{array}{l}-0.009 * * * \\
(0.003)\end{array}$ & $\begin{array}{l}-0.009 * * \\
(0.003)\end{array}$ & $\begin{array}{l}0.120 * * * \\
(0.013)\end{array}$ & $\begin{array}{l}0.085 * * * \\
(0.013)\end{array}$ \\
\hline Hispanic & $\begin{array}{l}-0.102 * * * \\
(0.016)\end{array}$ & $\begin{array}{l}-0.097 * * * \\
(0.016)\end{array}$ & $\begin{array}{l}-0.010^{*} \\
(0.005)\end{array}$ & $\begin{array}{l}-0.010^{*} \\
(0.005)\end{array}$ & $\begin{array}{l}0.035 * * \\
(0.017)\end{array}$ & $\begin{array}{l}0.031 * \\
(0.016)\end{array}$ \\
\hline Age & $\begin{array}{l}-0.008 * * * \\
(0.0009)\end{array}$ & $\begin{array}{l}-0.007 * * * \\
(0.0009)\end{array}$ & $\begin{array}{l}-0.0007 * * \\
(0.0003)\end{array}$ & $\begin{array}{l}-0.0007 * * \\
(0.0003)\end{array}$ & $\begin{array}{l}-0.006^{* * *} \\
(0.0009)\end{array}$ & $\begin{array}{l}-0.007 * * * \\
(0.0009)\end{array}$ \\
\hline Years of education & $\begin{array}{l}-0.015^{* * * *} \\
(0.001)\end{array}$ & $\begin{array}{l}-0.013 * * * \\
(0.001)\end{array}$ & $\begin{array}{l}-0.002 * * * \\
(0.0005)\end{array}$ & $\begin{array}{l}-0.002 * * * \\
(0.0005)\end{array}$ & $\begin{array}{l}-0.0061 \\
(0.001)\end{array}$ & $\begin{array}{l}-0.001 \\
(0.001)\end{array}$ \\
\hline Married & $\begin{array}{l}-0.109^{* * * *} \\
(0.008)\end{array}$ & $\begin{array}{l}-0.106^{* * * *} \\
(0.008)\end{array}$ & $\begin{array}{l}-0.017 * * * \\
(0.003)\end{array}$ & $\begin{array}{l}-0.017 * * * \\
(0.003)\end{array}$ & $\begin{array}{l}0.014 * \\
(0.008)\end{array}$ & $\begin{array}{l}0.012 \\
(0.008)\end{array}$ \\
\hline Health factor 1 & $\begin{array}{l}-0.001 \\
(0.011)\end{array}$ & & $\begin{array}{l}0.004 \\
(0.004)\end{array}$ & & $\begin{array}{l}0.059 * * * \\
(0.011)\end{array}$ & \\
\hline Health factor 2 & $\begin{array}{l}-0.010^{* * * *} \\
(0.003)\end{array}$ & & $\begin{array}{l}-0.003 * * \\
(0.001)\end{array}$ & & $\begin{array}{l}-0.010^{* * * *} \\
(0.004)\end{array}$ & \\
\hline Health factor 3 & $\begin{array}{l}-0.005 \\
(0.004)\end{array}$ & & $\begin{array}{l}0.0003 \\
(0.001)\end{array}$ & & $\begin{array}{l}-0.035^{* * * *} \\
(0.004)\end{array}$ & \\
\hline Health factor 4 & $\begin{array}{l}-0.026^{* * *} \\
(0.004)\end{array}$ & & $\begin{array}{l}0.003 * * \\
(0.001)\end{array}$ & & $\begin{array}{l}-0.060 * * * \\
(0.004)\end{array}$ & \\
\hline $\begin{array}{l}\text { Household income } \\
\text { (in } 1,000 \text { USD) }\end{array}$ & $\begin{array}{l}-0.00008 * * * \\
(0.00002)\end{array}$ & $\begin{array}{l}-0.00008 * * * \\
(0.00002)\end{array}$ & $\begin{array}{l}<0.00001 \\
(<0.00001)\end{array}$ & $\begin{array}{l}<0.00001 \\
(0.00001)\end{array}$ & $\begin{array}{l}-0.00003 \\
(0.00003)\end{array}$ & $\begin{array}{l}-0.00003 \\
(0.00003)\end{array}$ \\
\hline $\begin{array}{l}\text { Household wealth } \\
\text { (in } 1,000 \text { USD) }\end{array}$ & $\begin{array}{l}-0.00001 * * * \\
(<0.00001)\end{array}$ & $\begin{array}{l}-0.00001 * * * \\
(<0.00001)\end{array}$ & $\begin{array}{l}<0.00001 \\
(<0.00001)\end{array}$ & $\begin{array}{l}<0.00001 \\
(<0.00001)\end{array}$ & $\begin{array}{l}<0.00001 \\
(<0.00001)\end{array}$ & $\begin{array}{l}<0.00001 \\
(<0.00001)\end{array}$ \\
\hline Risk tolerance & $\begin{array}{l}0.068 * * * \\
(0.024)\end{array}$ & $\begin{array}{l}0.065 * * * \\
(0.024)\end{array}$ & $\begin{array}{l}0.019 * * \\
(0.009)\end{array}$ & $\begin{array}{l}0.020 * * \\
(0.009)\end{array}$ & $\begin{array}{l}-0.042 * \\
(0.024)\end{array}$ & $\begin{array}{l}-0.033 \\
(0.023)\end{array}$ \\
\hline $\begin{array}{l}\text { Father has high } \\
\text { school degree }\end{array}$ & $\begin{array}{l}0.004 \\
(0.008)\end{array}$ & $\begin{array}{l}0.007 \\
(0.008)\end{array}$ & $\begin{array}{l}0.0005 \\
(0.003)\end{array}$ & $\begin{array}{l}0.0007 \\
(0.003)\end{array}$ & $\begin{array}{l}-0.017 * \\
(0.008)\end{array}$ & $\begin{array}{l}-0.018 * * \\
(0.008)\end{array}$ \\
\hline $\begin{array}{l}\text { Mother has high } \\
\text { school degree }\end{array}$ & $\begin{array}{l}0.001 \\
(0.008)\end{array}$ & $\begin{array}{l}0.001 \\
(0.008)\end{array}$ & $\begin{array}{l}0.002 \\
(0.003)\end{array}$ & $\begin{array}{l}0.002 \\
(0.003)\end{array}$ & $\begin{array}{l}0.002 \\
(0.008)\end{array}$ & $\begin{array}{l}0.002 \\
(0.008)\end{array}$ \\
\hline R-squared & 0.05 & 0.06 & 0.02 & 0.02 & 0.05 & 0.08 \\
\hline $\begin{array}{l}\text { Hansen } J \text { - Statistic } \\
(\mathrm{P}-\text { value })\end{array}$ & $\begin{array}{l}13.542 \\
(0.699)\end{array}$ & $\begin{array}{l}14.300 \\
(0.645)\end{array}$ & $\begin{array}{l}24.135 \\
(0.115)\end{array}$ & $\begin{array}{l}23.690 \\
(0.128)\end{array}$ & $\begin{array}{l}20.038 \\
(0.272)\end{array}$ & $\begin{array}{l}20.328 \\
(0.257)\end{array}$ \\
\hline Observations & 43,963 & 43,963 & 44,238 & 44,238 & 44,238 & 44,238 \\
\hline
\end{tabular}

* significant at $10 \% ; * *$ significant at $5 \%$; *** significant at $1 \%$

Huber-White standard errors in brackets, clustered at respondent level.

Wave fixed effects and birth region dummies are included but their coefficients are not shown.

${ }^{+}$All the health indicators listed in Table 1 are included, but their coefficients are not shown. 


\section{Discussion Paper Series}

Mannheim Research Institute for the Economics of Aging Universität Mannheim

To order copies, please direct your request to the author of the title in question.

\begin{tabular}{|c|c|c|c|}
\hline Nr. & Autoren & Titel & Jahr \\
\hline $101-06$ & $\begin{array}{l}\text { Melanie Lührmann } \\
\text { Matthias Weiss }\end{array}$ & $\begin{array}{l}\text { Market Work, Home Production, Consumer } \\
\text { Demand and Unemployment among the } \\
\text { Unskilled }\end{array}$ & 06 \\
\hline $102-06$ & $\begin{array}{l}\text { Hans-Martin von } \\
\text { Gaudecker } \\
\text { Rembrandt D. Scholz }\end{array}$ & Lifetime Earnings and Life Expectancy & 06 \\
\hline $103-06$ & $\begin{array}{l}\text { Dirk Krueger } \\
\text { Alexander Ludwig }\end{array}$ & $\begin{array}{l}\text { On the Consequences of Demographic Change } \\
\text { for Rates of Returns to Capital, and the } \\
\text { Distribution of Wealth and Welfare }\end{array}$ & 06 \\
\hline $104-06$ & $\begin{array}{l}\text { Karsten Hank, } \\
\text { Hendrik Jürges, } \\
\text { Jürgen Schupp, } \\
\text { Gert G. Wagner }\end{array}$ & $\begin{array}{l}\text { Die Messung der Greifkraft als objektives } \\
\text { Gesundheitsmaß in sozialwissenschaftlichen } \\
\text { Bevölkerungsumfragen: Erhebungsmethodische } \\
\text { und inhaltliche Befunde auf der Basis von } \\
\text { SHARE und SOEP }\end{array}$ & 06 \\
\hline $105-06$ & Hendrik Jürges & $\begin{array}{l}\text { True health vs. response styles: Exploring cross- } \\
\text { country differences in self-reported health }\end{array}$ & 06 \\
\hline $106-06$ & $\begin{array}{l}\text { Christina Benita } \\
\text { Wilke }\end{array}$ & $\begin{array}{l}\text { Die ökonomischen Auswirkungen des } \\
\text { demographischen Wandels in Bayern }\end{array}$ & 06 \\
\hline $107-06$ & Barbara Berkel & $\begin{array}{l}\text { Retirement Age and Preretirement in German } \\
\text { Administrative Data }\end{array}$ & 06 \\
\hline $108-06$ & $\begin{array}{l}\text { Hans-Martin von } \\
\text { Gaudecker } \\
\text { Carsten Weber }\end{array}$ & $\begin{array}{l}\text { Mandatory Unisex Policies and Annuity Pricing: } \\
\text { Quasi-Experimental Evidence from Germany }\end{array}$ & 06 \\
\hline $109-06$ & Daniel Schunk & $\begin{array}{l}\text { The German SAVE Survey: Documentation and } \\
\text { Methodology }\end{array}$ & 06 \\
\hline $110-06$ & Barbara Berkel & $\begin{array}{l}\text { THE EMU and German Cross Border Portfolio } \\
\text { Flows }\end{array}$ & 06 \\
\hline $111-06$ & Martin Salm & $\begin{array}{l}\text { Can subjective mortality expectations and stated } \\
\text { preferences explain varying consumption and } \\
\text { saving behaviors among the elderly? }\end{array}$ & 06 \\
\hline $112-06$ & $\begin{array}{l}\text { Daniel Houser, } \\
\text { Daniel Schunk, } \\
\text { Joachim Winter }\end{array}$ & Trust Games Measure Trust & 06 \\
\hline $113-06$ & $\begin{array}{l}\text { Hanming Fang, } \\
\text { Michael Keane, } \\
\text { Ahmed Khwaja, } \\
\text { Martin Salm, } \\
\text { Dan Silverman }\end{array}$ & $\begin{array}{l}\text { Testing the Mechanisms of Structural Models: } \\
\text { The Case of the Mickey Mantle Effect }\end{array}$ & 06 \\
\hline
\end{tabular}


